\title{
Diyetle Mikro Besin Ögesi Alımlarının Değerlendirilmesi
}

\author{
Dietary Assessment of Micronutrients Intake
}

\author{
Elif Uluğ $\breve{1}^{1}$ Neslişah Rakıcıoğlu ${ }^{2}$
}

Geliş tarihi/Received: 25.10.2019 • Kabul tarihi/Accepted: 30.12.2019

\section{ÖZET}

Besin tüketim araştırmalarının sonuçları, tüketicilerin besin tüketim eğilimlerini belirleyebilmek, risk değerlendirmesi yapabilmek, sağlık politikaları uygulayabilmek ve tüketicilerin zararlı maddelere maruziyet düzeylerini saptayabilmek için önemli verilerdir. Sağlıklı bir diyetin parçası olarak mikro besin ögeleri birçok metabolik olayda yer aldıkları ve vücudun normal işleyişini sürdürülebilmesi için gerekli iken bireysel olarak günlük mikro besin ögesi alımlarının değerlendirilmesinde güçlükler bulunmaktadır. Diyet ile mikro besin ögesi alımlarının değerlendirilmesinde birçok yöntem kullanılmasına rağmen epidemiyolojik çalışmalar için güvenilir ve geçerli evrensel bir yöntem bulunmamaktadır. Diyetle mikro besin ögesi alımlarının değerlendirilmesinde temelde referans olarak miktarlı beslenme günlükleri yöntemi kullanılmaktadır. Ancak bu yöntemin kullanımının zor olması ve büyük popülasyonlara uygulama güçlükleri nedeniyle daha pratik yöntemler için geçerlilik/güvenilirlik çalışmaları yapılmıştır. Bu noktada besin tüketim sıklığının özellikle büyük gruplarda kullanılabilir olduğu görülmektedir. Ancak doğru sonuçlar alabilmek için besin tüketim sıklığı sorgulanırken saptanmak istenen besin ögesine göre besin yelpazesinin geliştirilmesi önemli olmaktadır. Sonuç olarak besin tüketim araştırmasında saptanmak istenen besin ögesinin hangi yöntem ile daha doğru sonuç vereceği ve araştırma yapılacak popülasyonun iyi tanımlanabilmesi, sonuçların doğruluğu açısından önemli olmaktadır.

Anahtar kelimeler: Beslenme, besin tüketim araştırmaları, mikro besin ögeleri, diyet

\section{ABSTRACT}

The results of food consumption surveys are important data for determination of food consumption trends of consumers, risk assessment, applying health policies, and determination of exposure of consumers to harmful substances. While micronutrients are essential for taking part in many metabolic processes and maintaining the proper functioning of the body, there are difficulties in evaluating of daily intake of micronutrients individually. Although many methods are used in the evaluation of the dietary micronutrient intake, there is no universal, reliable, and valid method for epidemiological studies. In the evaluation of dietary intake of micronutrients, weighted food diary method is used as a basis for reference. However, because this method is difficult to use and apply to large populations, validation studies have been conducted for more practical methods. At this point, it is seen that the food frequency questionnaire might be used especially in large groups. Nonetheless, in order to obtain reliable results, it is important to develop the food range according to the nutrients to be determined when querying the food frequency questionnaire. In conclusion, in order to find the most reliable method in food consumption research, it is important to the nutrient types to be determined and to define the population well.

Keywords: Nutrition, food consumption survey, micronutrients, diet

\footnotetext{
1. Hacettepe Üniversitesi Sağlık Bilimleri Fakültesi Beslenme ve Diyetetik Bölümü, Ankara, Türkiye

(1) https://orcid.org/0000-0003-4759-892X
}

2. İletişim/Correspondence: Hacettepe Üniversitesi Sağlık Bilimleri Fakültesi Beslenme ve Diyetetik Bölümü, Ankara, Türkiye E-posta: neslisah@hacettepe.edu.tr • io https://orcid.org/0000-0001-8763-7407 


\section{GİRIŞ}

Besin tüketim araştırmaları; tüketicilerin besin tüketim eğilimlerini belirleyebilmek, sağlık politikaları uygulayabilmek, risk değerlendirmesi yapabilmek, tüketicilerin zararlı maddelere (pestisit vb.) ve mikrobiyolojik bulaşanlara maruziyet düzeylerini saptayabilmekiçin önemliveriler sağlayan araştırmalardır (1, 2). Ancak bu araştırmalarda kullanılacak yöntemlerin çeşitliliği ve her yöntemin hem olumlu yönleri hem de sinirlllıklarının bulunmasından dolayı, epidemiyolojik araştırmalar için kullanılabilecek evrensel standart bir yöntem bulunmamaktadır (1). Bu nedenle kullanılacak yöntemin araştırma yapılacak toplumun özelliklerine ve tüketim miktarı saptanmak istenen besin ve/veya besin ögelerine uygun olarak seçilmesi gerekmektedir. $\mathrm{Bu}$ bağlamda, ulusal düzeyde araştırma yöntemleri kullanılmasına rağmen, bireyin hangi besini hangi miktarda tükettiğinin saptanabilmesi için bireysel besin tüketim değerlendirmesi gerekmektedir (3).

Sağlıklı bir diyetin parçası olarak makro ve mikro besin ögelerinin çok büyük bir kısmı vücut işlevlerinin yerine getirilebilmesi için elzemdir. Bu açıdan, mikro besin ögelerinin enerji homeostazl, kas ve kemik gelişimi, gen ekspresyonu, kan hücrelerinin yapımı, immün sistem ve antioksidan savunma sistemi gibi birçok önemli noktada görevleri bulunmaktadır. Bu başlık altında suda veya yağda çözünen vitaminler ile makro ve mikro mineraller incelenmektedir (46). Mikro besin ögeleri; vücutta birçok metabolik olaylarda yer almaları ve vücudun normal işleyişinin sürdürülmesi için gerekli iken, bireysel olarak günlük alımlarının değerlendirilmesinde güçlükler bulunmaktadır (2). Çünkü vitamin ve minerallerin besinlerdeki miktarları, besinin yetiştiği toprak ve sulama koşulları ya da hazırlama ve pişirme yöntemleri gibi faktörlerden etkilenebilmektedir $(4,5)$. Bu bağlamda, bireylerin makro besin ögeleri alımlarının değerlendirilmesi için besin kayıt yöntemi, 24 saatlik geriye dönük besin tüketim kayıtları, besin tüketim sıklığı, diyet öyküsü ya da besin tüketimlerinin gözlenmesi gibi farklı yöntemler kullanılmasına rağmen epidemiyolojik çalışmalar için geçerli ve güvenilir evrensel bir yöntem bulunmamaktadır (1). $\mathrm{Bu}$ nedenle, bu derleme literatürde farklı besin tüketimi değerlendirme yöntemleri ile diyetle mikro besin ögelerinin alımlarının saptanması için yapılan geçerlilik ve güvenilirlik çalışmalarını derlemek amacıyla yazılmıştır.

\section{Besin Tüketimini Değerlendirme Yöntemleri}

Diyetle besin ögesi alımları değerlendirilirken hangi araştırma yönteminin kullanılacağı, saptanmak istenen besin ögesine ve araştırılacak grubun özelliklerine göre değişiklik gösterebilmektedir $(3,7)$. Araştırma türleri ulusal ve bireysel düzeyde uygulanan yöntemler olabilmektedir. Ulusal düzeyde besin tüketimi araştırma yöntemleri daha çok toplumun genel tüketimi ile ilgili veriler sağlamaktadır $(1,8)$. Ancak yaş grubuna, cinsiyete ya da herhangi bir hastalık olup olmaması durumuna göre bireysel besin tüketim durumlarını saptayabilmek için her bireyin hangi besini hangi miktarda tükettiğinin belirlenmesi gerekmektedir $(3,7)$.

Bireysel besin tüketimlerini değerlendirmek için besin kayıt yöntemi (günlük tutma), besin tüketim sıklığı, 24 saatlik geriye dönük besin tüketim kayıtları, diyet öyküsü ya da besin tüketimlerinin gözlenmesi yöntemleri kullanılmaktadır (1,2,7). Bunlardan besin kayıt ya da diğer adıyla günlük tutma yöntemi bir veya daha fazla günde tüketilen her besin ve içeceğin tüketici tarafından tüketildiği anda kaydedilmesi esasına dayanmaktadır. Yöntem hatırlanmaya bağlı olmadığı için hata olasılığı azdır. Ayrıca kayıtlar tüketilen yiyecek ve içeceğin miktarları ile birlikte yapılmışsa oldukça güvenilir sonuçlar vereceğinden altın standart olarak değerlendirilmektedir. Ancak kişinin doğru kayıt tutabilmesi için araştırmacı ile iş birliği içinde olması gerekmektedir $(2,8)$.

Besin tüketim sıklığı ise listelenmiş bazı besinlerin belirlenen bir zaman aralığı içinde tüketim sıklığının miktarlı veya miktarsı olarak kaydedilmesi esasına dayanmaktadır ve buradan bireyin günlük aldığı makro ve mikro besin ögelerinin miktarları 
hesaplanabilmektedir (7). Bu yöntemde bireyin genel tüketim alışkanlıkları sorgulanır, sorular standart olduğu için maliyeti düşük ve kolay uygulanabilir bir yöntemdir.Ancakdetaylartamolaraksorgulanamadığı ve miktarlar yaklaşık olarak hesaplandığı için net sonuçlar alınamamaktadır. Buna rağmen, özellikle büyük örnekleme sahip epidemiyolojik çalışmalarda, hem uygulanabilirliğinin kolay olması hem de maliyetinin düşük olmasından dolayı sıklıkla tercih edilmektedir (2,8). Ancak ülkemizde listelenmiş besinlerin fazlalığı, karışık tencere yemeği tüketimine bağlı olarak besin ve yemeklerde kullanılan malzeme çeşitliliği nedeniyle bu yöntemin uygulanması daha fazla zaman almakta ve araştırmacı tarafindan tüketimin iyi sorgulanması gerekmektedir (7).

Diğer bir yöntem olan 24 saatlik geriye dönük besin tüketim kayıtları, bireyin son 24 saat içerisinde tükettiği yiyecek ve içeceklerin detaylı olarak kaydedilmesi esasına dayanmaktadır (7). Tek bir gün veri toplanacağı için bireyin olağan beslenme durumunu yansıtmayabilir. $\mathrm{Bu}$ nedenle eğer bir günden fazla kayıt alınacaksa birbirini tekrar eden günlerde alınması ve hafta içi ile hafta sonu günlerini de kapsaması, bireyin genel alışkanlıklarını göstermede daha avantajlı olmaktadır (7). Besin tüketiminin gözlenmesi ise klinik uygulamalarda yaygın olarak kullanılmakla birlikte, özellikle büyük gruplarda uygulanmasının zorluğu nedeniyle kullanımı tercih edilmemektedir $(2,8)$.

Bireysel besin tüketimlerinin doğru ve güvenilir şekilde belirleyen evrensel epidemiyolojik standart bir yöntem bulunmadığı için yöntem seçimi, yapılacak çalışmanın amacına ve saptanmak istenen besin ve besin ögelerine göre değişebilmektedir $(1,2,8)$. Epidemiyolojik çalışmalarda en çok kullanılan yöntem besin tüketim sıklı̆̆ı olmasına rağmen, besin kayıt yöntemi ve 24 saatlik geriye dönük besin tüketim kayıtları da sıklıkla kullanılmaktadır (9).

\section{Diyetle Vitamin Alımlarının Değerlendirilmesi}

Suda çözünen vitamin alımlarının
değerlendirilmesi: Suda çözünen vitaminler grubuna B grubu vitaminleri (tiamin, riboflavin, niasin, pantotenik asit, piridoksin, folik asit ve $\mathrm{B}_{12}$ vitamini) ve $\mathrm{C}$ vitamini dahil edilmektedir. $\mathrm{Bu}$ vitaminlerin vücutta enerji, karbonhidrat ve lipit metabolizmasının regülasyonu, büyüme ve gelişme, gen ekspresyonu, antioksidan savunma sistemleri gibi birçok metabolik fonksiyonları bulunmaktadır $(4,5,10)$. Fonksiyonlarının bu kadar çeşitli ve yaşam için önemli olması, bu vitaminlerin diyetle alımlarının yeterli olmasını gerektirmektedir. $\mathrm{Bu}$ nedenle literatürde suda çözünen vitaminlerin diyetle alımının değerlendirilmesi amacıyla yapılan geçerlilikgüvenilirlik çalışmaları sıklıkla yer almaktadır. Yapılan geçerlilik güvenilirlik çalışmalarında 7 günlük miktarlı beslenme günlükleri $(11,12)$ veya bir günlük miktarlı beslenme günlüğü $(13,14)$ yöntemi ile besin tüketim sıklığı sonuçları karşılaştırıldığında; tiamin, riboflavin, niasin, folik asit, $B_{12}$ vitamini ve $C$ vitamini alımının değerlendirilmesinde besin tüketim sıklığı yönteminin kullanımının daha güvenilir olacağı gösterilmiştir. Benzer şekilde riboflavin, folik asit ve $C$ vitaminleri için son bir yılı kapsayacak besin tüketim sıklığı sonuçlarının üç ardışık günü kapsayacak beyana dayalı besin tüketim kayıtlarının sonuçları ile korelasyon gösterdiği bildirilmiştir (15). Diğer yandan C vitamini alımının değerlendirilmesinde; 28 günlük miktarlı besin tüketim kaydı sonuçları ile karşılaştırıldığında miktarlı besin tüketim sıklığının doğru sonuçlar vereceği ve kullanılabileceği sonucuna varılmıştır (16). Ancak farklı olarak, altı günü kapsayan 24 saatlik geriye dönük besin tüketim kayıtlarındaki sonuçlar ile miktarlı besin tüketim sıklığı sonuçlarının, folik asit ve C vitamini için korelasyon göstermediği de bildirilmiştir (17). Sonuç olarak; bireysel tüketim miktarı saptanmak istenen besin ögesine göre ayrıntılı bir şekilde düzenlenmiş besin tüketim sıklığı yönteminin miktarlı beslenme günlüğü yöntemi ile benzer sonuçlar verebileceği görülmektedir.

Anne sütü almayan 6 aylık bebeklerde referans olarak 4 günlük miktarlı beslenme günlüklerinden elde edilen sonuçlar ile karşılaştırıldığında bebek besinleri ve devam sütleri gibi besinleri de içeren 
15 günlük besin tüketim sıklığı sonuçlarının; tiamin, riboflavin, niasin, piridoksin, folik asit, $\mathrm{B}_{12}$ vitamini ve $C$ vitamini alımı için kullanılabileceği bildirilirken (18), 12 aylık bebeklerde sadece tiamin, riboflavin, niasin, $\mathrm{B}_{6}$ ve $\mathrm{C}$ vitaminleri için uygulanabilir olduğu gösterilmiştir (19). Okul çağı çocuklarında yapılan bir araştırmada hem kız hem erkek çocuklarda miktarlı beslenme günlüklerinin sonuçları referans olarak kabul edildiğinde ise; besin tüketim sıklığı ve 24 saatlik geriye dönük besin tüketim kayıtlarının tiamin, folik asit ve C vitamini alım düzeylerinin saptanmasında kullanılabileceği bildirilmiştir. $\mathrm{Bu}$ çalışmanın adölesan grubunda ise suda çözünen vitamin alımları açısından miktarlı besin tüketim kayıtları ile karşılaştırıldığında ne besin tüketim sıklığı ne de 24 saatlik geriye dönük besin tüketim kayıtları için anlamlı bir korelasyon saptanamamıştır (20). Diğer yandan başka bir çalışmada adölesanlara özgü besin tüketim sıklığı ile karşılaştırıldığında ardışık 3 günü kapsayan geriye dönük besin tüketim kayıtlarının $\mathrm{C}$ vitamini alım düzeyinin saptanmasında kullanılabileceği göstermiştir (21). Yaşlı bireylerde ise niasin $(22), B_{6}$ vitamini, folik asit $(23,24)$ ve $C$ vitamini (22-24) için 5 gün süreyle uygulanan, 24 saatlik geriye dönük besin tüketim kayıtları sonuçlarının, resimli besin tüketim sıklığı ile toplanan verilerden elde edilen sonuçlar ile korele olduğu saptanmıştır. Gebelerde yapılan bir çalışmada gebeliğin 25. haftasındaki bireylerde yedi günlük miktarlı besin tüketim kayıtları ile besin tüketim sıklığı anketleri karşılaştırıldığında; günlük folik asit alımı için tutarlı olduğu gözlenmiştir (25). Gebeliğin 12.-18. haftaları arasında ise besin tüketim sıklığı sonuçları ile 24 saatlik besin tüketim kayıtları tiamin, riboflavin, niasin, $\mathrm{B}_{6}$ vitamini, folik asit, pantetonik asit (26), $B_{12}$ vitamini (27) ve $C$ vitamini $(26,27)$ için korele bulunmuştur.

Çalışmaların sonuçları değerlendirildiğinde; kullanılan besin tüketim sıklığının içerdiği besinlerin ayrıntılı olarak listelenmiş olup olmadığının ya da beslenme günlükleri ve 24 saatlik geriye dönük besin tüketim kayıtlarının genel tüketimi ne kadar yansıttığının, sonuçlar açısından önemli olduğu görülmektedir (11-16, 28, 29). Özetle; diyetle suda çözünen vitaminlerin alımlarının değerlendirilmesi üzerine yapılan birçok geçerlilik ve güvenilirlik çalışmasında referans yöntem olarak sıklıkla tercih edilen miktarlı beslenme günlüklerinin, besin tüketim sıklığı ile tutarlı sonuçlar verdiği ve besin tüketim sıklığı yönteminin özellikle büyük popülasyonlarda diyetle suda çözünen vitaminlerin günlük alımlarının saptanmasında uygun olabileceği rapor edilmiştir (9, $28,29)$.

Yağda çözünen vitamin alımlarının değerlendirilmesi: Yağda çözünen vitaminler grubuna $\mathrm{A}, \mathrm{D}, \mathrm{E}$ ve $\mathrm{K}$ vitamini dahil olmaktadır. $\mathrm{Bu}$ vitaminlerin genel olarak gen ekspresyonu, pıhtılaşma faktörlerinin sentezi, büyüme-gelişme veya görme gibi işlevleri bulunmaktadır $(4,6,10)$. Bu nedenle, yağda çözünen vitaminlerin bireysel olarak alımlarının güvenilir bir şekilde değerlendirilmesi amacıyla kullanılabilecek yöntemler ile ilgili birçok geçerlilik ve güvenilirlik çalışması literatürde yer almaktadır. $\mathrm{Bu}$ bağlamda yapılan geçerlilik ve güvenilirlik çalışmalarında yedi günlük miktarlı beslenme günlükleri ile besin tüketim sıklığı sonuçları karşılaştırıldığında; retinol $(12,13)$ ve E vitamini (11) alımının saptanmasında besin tüketim sıklığının kullanılabileceği gösterilmiştir. Yine 28 günlük miktarlı besin tüketim kaydı sonuçları ile karşılaştırıldığında miktarlı besin tüketim sıklığının; $\mathrm{A}, \mathrm{D}$ ve $\mathrm{E}$ vitaminlerinin günlük alımlarının değerlendirilmesinde doğru sonuçlar vereceği ve kullanılabileceği bildirilmiştir (16). Benzer şekilde altı günü kapsayan 24 saatlik geriye dönük besin tüketim kayıtlarındaki sonuçlar ile miktarlı besin tüketim sıklığı sonuçlarının; A vitamini ve E vitamini alım düzeylerinin saptanmasinda orta derecede korelasyon gösterdiği rapor edilmiştir (17). Başka bir çalışmada bir günü hafta içi ve bir günü hafta sonuna gelecek şekilde alınan 24 saatlik geriye dönük besin tüketim kayıtlarının sonuçlarının miktarlı besin tüketim sıklığı sonuçları ile karşılaştırıldığında; A, E ve D vitaminleri için korele olduğu saptanmıştır (30, 31). Ancak yedi günlük miktarlı beslenme günlüğü ile karşılaştırıldığında, besin tüketim sıklığının A vitamini (12) ve E vitamini (14) alım düzeylerinin 
saptanması için tutarlı sonuçlar vermediğini gösteren çalışmalar da bulunmaktadır. Bu bağlamda, besin tüketim sıklığı ve 24 saatlik geriye dönük besin tüketim kaydı yöntemlerinin miktarlı beslenme günlükleri ile benzer sonuç vereceği ve özellikle büyük gruplarda kullanım kolaylıkları nedeniyle tercih edilebileceği görülmektedir.

Anne sütü almayan 6 aylık bebeklerde, referans olarak dört günlük miktarlı beslenme günlüklerinin sonuçları ile bebeklere özel geliştirilmiş son 15 günü kapsayan besin tüketim sıklığı yönteminin sonuçları karşılaştırıldığında, retinol, E ve D vitaminlerinin günlük alımlarının değerlendirilmesinde kullanılabileceği (18), 12 aylık bebeklerde ise sonuçların sadece retinol ve E vitamini için tutarlı olduğu gösterilmiştir (19). Okul çağı çocuklarında yapılan bir araştırmada; kız çocuklarda miktarlı besin tüketim kaydı sonuçları referans olarak kabul edildiğinde, 24 saatlik geriye dönük besin tüketim kayıtları sonuçlarının retinol alımı için korele olduğu saptanmıştır. Adölesan grupta ise yağda çözünen vitaminler açısından miktarlı besin tüketim kayıtları ile karşılaştırıldığında ne besin tüketim sıklığı ne de 24 saatlik geriye dönük besin tüketim kayıtlarının sonuçları arasında anlamlı bir korelasyonun olmadığı gösterilmiştir (20). Yaşlı bireylerde 5 günlük 24 saatlik geriye dönük besin tüketim kayıtları sonuçları ile fotoğraflı ve miktarlı besin tüketim sıklığı sonuçlarının A, E vitaminleri (22), D vitamini (23) ya da K vitamini için (24) tutarlı olduğu bildirilmiştir. Gebelerde ise yapllan güncel bir çalışmada D vitaminine özel olarak geliştirilmiş besin tüketim sıklığı formunun, hem miktarlı besin tüketim sıklığı ile hem de serum 25-hidroksi vitamin D düzeyi ile tutarlı olduğu gösterilmiştir (32). Gebeliğin 25. haftasındaki kadınlarda 7 günlük miktarlı besin tüketim kayıtları ile besin tüketim sıklığı sonuçları karşılaştırıldığında; retinol alımı için korele olduğu gözlenmiştir (25). Aynı zamanda, gebeliğin 12.-18. haftaları arasında besin tüketim sıklığı sonuçları ile 24 saatlik besin tüketim kayıtları sonuçlarının A vitamini (27), D vitamini (26) ve E vitamininin $(26,27)$ günlük alım düzeyinin saptanması için tutarlı olabileceği bulunmuştur.
Yağda çözünen vitaminlerinbireyselolarakalımlarının değerlendirilmesi amacıyla yapılan çalışmalarda genellikle besin tüketim sıklığı ile beslenme günlükleri ya da besin tüketim kaydı sonuçlarının karşılaştırıldığı görülmektedir (11-13, 30-32). Bu açıdan, uygulanan besin tüketim sıklığı formundaki besinlerin çeşitliliği, uygulanan yaş grubu için formun uygun olması gibi faktörler sonuçları etkilemektedir. Aynı zamanda bazı besinlerde yüksek konsantrasyonda bulunan vitaminlerin günlük alımlarının saptanmasında küçük değişikliklerin bile sonucu etkileyebileceği göz önünde bulundurulmalıdır (örneğin; karaciğerdeki A vitamini). Özetle; diyetle yağda çözünen vitaminlerin alımlarının değerlendirilmesi üzerine yapılan birçok geçerlilik ve güvenilirlik çalışmasında referans yöntem olarak sıklıkla tercih edilen miktarlı beslenme günlükleri veya besin tüketim kayıtlarının, besin tüketim sıklığı ile tutarlı sonuçlar verdiği ve özellikle ayrıntılı bir şekilde hazırlanmış olan besin tüketim sıklığı formunun, diyetle yağda çözünen vitaminlerin alımlarının saptanmasında uygun olabileceği rapor edilmiştir (9, 29).

\section{Diyetle Mineral Alımlarının Değerlendirilmesi}

Majör mineral alımlarının değerlendirilmesi: Günlük gereksinmesi ve vücutta bulunma miktarları yüksek olan mineraller majör mineraller olarak tanımlanmaktadır. Bu başlık altında kalsiyum, fosfor, magnezyum, sodyum, potasyum gibi mineraller incelenmektedir. $\mathrm{Bu}$ minerallerin kemik gelişimi, enerji, sıvı ve elektrolit homeostazl, gen ekspresyonu ve sinir iletimi gibi birçok fonksiyonları bulunduğu için diyetle yeterli alımlarının değerlendirilmesi büyük önem arz etmektedir $(5,6)$.

Bu konudaki geçerlilik ve güvenilirlik çalışmalarında yedi günlük miktarlı beslenme günlükleri ile besin tüketim sıklığı sonuçları karşılaştırıldığında kalsiyum (11-13), magnezyum, potasyum $(12,14,16)$, fosfor (12, 13) ve sodyum $(13,16)$ alımının değerlendirilmesinde besin tüketim sıklığının kullanılmasının güvenilir olacağı gösterilmiştir. Aynı zamanda son bir yılı kapsayacak şekilde miktarlı besin tüketim sıklığı sonuçlarının kalsiyum ve magnezyum için 3 ardışık 
günlük beyana dayalı besin tüketim kayıtlarının (15) veya bir gün hafta içi bir gün hafta sonu olacak şekilde 24 saatlik geriye dönük besin tüketim kayıtlarının (30) sonuçları ile anlamlı korelasyon gösterdiği bildirilmiştir. Ancak altı günü kapsayan 24 saatlik geriye dönük besin tüketim kayıtlarındaki sonuçların miktarlı besin tüketim sıklığı sonuçları ile magnezyum için orta derecede korelasyon gösterirken kalsiyum, sodyum ve potasyum için ilişkili olmadığ da saptanmıştır (17). Sonuç olarak; besin tüketim sıklığında yer alan besinlerin çeşitliliğinin farklı olması ya da 24 saatlik geriye dönük besin tüketim kayıtlarının bireylerin genel tüketim alışkanlıklarını yansıtamayabileceği nedenleri ile sonuçların farklı olabileceği görülmektedir.

Anne sütü almayan 6 aylık (18) veya 12 aylık (19) bebeklerde yapılan bir çalışmada referans olarak dört günlük miktarlı beslenme günlüklerinden elde edilen sonuçlar ile karşılaştırıldığında, ticari olarak satılan meyve sebze püreli, muhallebiler gibi bebek besinleri ve devam sütleri gibi besinleri de içeren son on beş günü kapsayan besin tüketim sıklığı sonuçlarının sodyum, kalsiyum, potasyum, magnezyum ve fosfor alımlarının değerlendirilmesinde uygun olabileceği bildirilmiştir. Okul çağı çocuklarında yapılan bir araştırmada ise kız çocuklarda miktarlı beslenme günlüklerinin sonuçları referans olarak kabul edildiğinde besin tüketim sıklığının kalsiyum alımı için kullanılabileceği gösterilmiştir, ancak bu sonuç erkek çocuklarda anlamlı bulunmamıştır. Bu çalışmanın adölesan grubunda ise miktarlı besin tüketim kayıtları ile karşılaştırıldığında ne besin tüketim sıklığı ne de 24 saatlik geriye dönük besin tüketim kayıtlarının majör mineraller açısından sonuçlar arasında anlamlı bir korelasyonunun olmadığı gösterilmiştir (20). Ancak, başka bir çalışmada adölesanlara özgü besin tüketim sıklığı ile karşılaştırıldığında üç günlük 24 saatlik geriye dönük besin tüketim kayıtlarının kalsiyum için kullanılabilir olduğu göstermiştir (21). Bu çalışmaların sonuçlarına göre; besin tüketim sıklığı yönteminin her yaş grubu için doğru sonuçlar vermeyeceği, özellikle adölesan grup için daha ayrıntılı bir besin tüketim sıklığı formunun oluşturulması gerektiği sonucuna varılmaktadır. Yaşlı bireylerde kalsiyum, fosfor, potasyum, sodyum (22) ve magnezyum (24) için beş günü kapsayan 24 saatlik geriye dönük besin tüketim kaydı sonuçlarının, resimli besin tüketim sıklığının sonuçları ile ilişkili olduğu saptanmıştır. Ayrıca kalsiyuma özel geliştirilmiş besin tüketim sıklığı sonuçları ile 24 saatlik geriye dönük besin tüketim kayıtları sonuçları yaşlı bireylerde ileri derecede korele bulunmuştur (33). Gebeliğinin 12-18. haftaları arasındaki kadınlarda ise besin tüketim sıklığı ile 24 saatlik besin tüketim kayıtları magnezyum, fosfor (26) ve kalsiyum (27) için tutarlı bulunmuştur.

Yapılan çalışmaların sonuçları değerlendirildiğinde (17, 20, 30); genellikle besin tüketim sıklığı sonuçları ile beslenme günlükleri veya besin tüketim kayıtları sonuçlarının tutarlı olduğu görülse de aksini bildiren çalışmalarda bulunmaktadır. Bu bağlamda, bireylerin tükettikleri besinlerin yanısıra içeceklerin kayıtlarının da iyi bir şeklide alınması sonuçların güvenilirliği açısından önemli olmaktadır. Özetle; diyetle majör minerallerin alımlarının değerlendirilmesi üzerine yapılan birçok geçerlilik ve güvenilirlik çalışmasında referans yöntem olarak sıklıkla tercih edilen miktarlı beslenme günlükleri veya besin tüketim kayıtlarının, besin tüketim sıklığı ile tutarlı sonuçlar verdiği gösterilse de besin tüketim sıklığı yönteminde kullanılacak formun saptanmak istenen mineral için daha ayrıntılı şekilde hazırlanması gerektiği görülmektedir $(28,29,34)$.

\section{Minör mineral alımlarının değerlendirilmesi:} Günlük gereksinmesi ve vücutta az miktarda bulunan mineraller minör mineraller olaraktanımlanmaktadır. $\mathrm{Bu}$ başlık altında demir, çinko, bakır, selenyum ve manganez gibi mineraller dahil edilmektedir. $\mathrm{Bu}$ minerallerin kan hücrelerinin yapımı, gen ekspresyonu, immün ve antioksidan savunma sistemi gibi birçok fonksiyonları bulunduğu için diyetle yeterli alınıp alınmadıklarının değerlendirilmesi büyük önem arz etmektedir $(4,5)$.

Diyetle minör mineral alımlarının değerlendirilmesi amacıyla yapılan geçerlilik ve güvenilirlik çalışmalarında 7 günlük miktarlı beslenme günlükleri 
ile besin tüketim sıklığı sonuçları karşılaştırıldığında demir (11-13), çinko (16), selenyum ve manganez $(12,14)$ alımlarının değerlendirilmesinde besin tüketim sıklığının kullanılmasının güvenilir olacağı gösterilmiştir. Aynı zamanda bir gün hafta içi ve bir gün hafta sonu olacak şekilde 24 saatlik geriye dönük besin tüketim kayıtlarının sonuçları miktarlı besin tüketim sıklığı sonuçları ile karşılaştırıldığında; demir, çinko, bakır ve selenyum minerallerinin alımlarının değerlendirilmesinde kullanılabileceği rapor edilmiştir $(17,30)$.

Bebeklik döneminin 6. (18) ve 12. aylarında (19) anne sütü almayan bebeklerde dört günlük miktarlı beslenme günlüklerinden elde edilen sonuçlar ile bebeklere özgü geliştirilmiş son on beş günü kapsayan besin tüketim sıklığı sonuçları karşılaştırıldığında; bu iki yöntemde demir, çinko ve bakır alımlarının ilişkili olduğu bildirilmiştir. Okul çağı çocuklarında yapılan bir araştırmada, kız çocuklarda miktarlı besin tüketim kaydı sonuçları referans olarak kabul edildiğinde besin tüketim sıklığının demir alımı için kullanılabileceği gösterilmiştir, ancak bu sonuç erkek çocuklarda anlamlı bulunmamıştır. Adölesan grupta ise miktarlı besin tüketim kayıtları ile karşılaştırıldığında ne besin tüketim sıklığı ne de 24 saatlik geriye dönük besin tüketim kayıtlarının minör minerallerin alımları için anlamlı bir sonuç göstermediği bildirilmiştir (20). Yaşlı bireylerde demir $(22,24)$ ve çinko $(22)$ için beş günü kapsayan 24 saatlik geriye dönük besin tüketim kaydı sonuçlarının resimli besin tüketim sıklığı sonuçları ile korele olduğu gösterilmiştir. Gebeliğin 12-18. haftaları arasındaki kadınlarda besin tüketim sıklığı sonuçları ile 24 saatlik besin tüketim kaydı sonuçlarının demir, çinko ve manganez için tutarlı olduğu bulunmuştur $(26,27)$.

Besinlerin yetiştiği toprağa, sulama koşullarına, mevsimler ve coğrafik farklılıklara göre minör mineral içeriklerinin değişebileceği bilinmektedir. Aynı zamanda bireylerin tükettikleri yiyecekler kadar içeceklerde günlük mineral alımına önemli katkı sağlamaktadır. Sonuç olarak; minör minerallerin diyetle alımlarının değerlendirilmesinde güvenilir yöntem olarak kabul edilebilecek miktarlı besin tüketim kayıtları ile besin tüketim sıklığı sonuçlarının genellikle ilişkili bulunduğu için değerlendirme yöntemi olarak daha az maliyet ve iş gücü gerektiren besin tüketim sıklığının kullanılabileceği bildirilmektedir $(29,34,35)$. Ancak besin tüketim sıklığı formunda yer alan besinlerin saptanmak istenen minerale göre çeşitlendirilmesi ve çalışmanın yapıldığı mevsimsel koşullarında sonuçları değiştirebileceği unutulmamalıdır.

\section{SONUÇ VE ÖNERİLER}

Diyetle mikro besin ögelerini alımlarının değerlendirilmesinde temelde referans olarak miktarlı beslenme günlükleri yöntemi kullanılmaktadır. Ancak bu yöntemin kullanımının zor olması nedeniyle daha pratik yöntemler için geçerlilik ve güvenilirlik çalışmaları yapılmıştır. Bu noktada besin tüketim sıklığının özellikle büyük gruplarda kullanılabilir olduğu görülmektedir. Ancak doğru sonuçlar alabilmek için besin tüketim sıklığı sorgulanırken saptanmak istenen besin ögesine göre besin yelpazesi ayrıntılı olarakgenişletilmelidir. Ayrıca Türk beslenme kültüründe birçok besini aynı anda içeren karışık besinlerin ve tencere yemeklerinin tüketimleri yaygın olduğu için besin tüketim sıklığını daha ayrıntılı sorgulamak gerekmektedir. Sonuç olarak; besin tüketim araştırmalarında kullanılacak yöntemin doğru seçilmesi sonuçlarının güvenilirliği açısından önemlidir. Bu konuda, saptanmak istenen besin ögeleri ile araştırmanın yapılacağı popülasyonun genel özellikleri ve beslenme alışkanlıkları göz önüne alınmalıdır.

Çıkar çatışması - Conflict of interest: Yazarlar çıkar çatışması olmadığını beyan ederler. - The authors declare that they have no conflict of interest.

\section{KAYNAKLAR}

1. Szücs V, Szabo E, Banati D. Short overview of food consumption databases. Czech J. Food Sci. 2013;31(6):5416.

2. Wasantwisut EU, Rosado J, Gibson R. Nutritional assessment: methods for selected micronutrients and calcium. Squires VR, editor. The Role of Food, 
Agriculture, Forestry and Fisheries in Human Nutrition. Oxford: Eolss Publishers; 2011. p. 1-13.

3. Shim JS, Oh K, Kim HC. Dietary assessment methods in epidemiologic studies. Epidemiol Health. 2014;36:e2014009.

4. Gropper SS, Smith JL, Groff JL. Advanced nutrition and human metabolism. 5th ed. California:Wadsworth; 2009.

5. Gibney MJ, Lanham-New SA, Cassidy A, Vorster HH. Introduciton to human nutrition. 2nd ed. New Jersey, USA: Blackwell Publishing; 2009.

6. Stipanuk M, Caudill, M. Biochemical, physiological and molecular aspects of human nutrition. 3th ed. New York, ABD: Elsevier; 2013.

7. Pekcan G. Beslenme durumunun saptanması. Ankara: T.C Sağlık Bakanlığı; 2008. 52 p.

8. Zuniga K, McAuley E. Considerations in selection of diet assessment methods for examining the effect of nutrition on cognition. J Nutr Health Aging. 2015;19(3):333-40.

9. Henriquez-Sanchez P, Sanchez-Villegas A, DoresteAlonso J, Ortiz-Andrellucchi A, Pfrimer K, Serra-Majem L. Dietary assessment methods for micronutrient intake: a systematic review on vitamins. Br J Nutr. 2009;102 Suppl 1:S10-37.

10. T.C Sağlık Bakanlığı. Türkiye’ye Özgü Besin ve Beslenme Rehberi. Ankara: Hacettepe Üniversitesi Sağlık Bilimleri Fakültesi Beslenme ve Diyetetik Bölümü; 2015. p 96.

11. Brunner E, Stallone D, Juneja M, Bingham S, Marmot M. Dietary assessment in Whitehall II: comparison of $7 \mathrm{~d}$ diet diary and food-frequency questionnaire and validity against biomarkers. Br J Nutr. 2001;86(3):40514.

12. Hodge A, Patterson AJ, Brown WJ, Ireland P, Giles G. The Anti Cancer Council of Victoria FFQ: relative validity of nutrient intakes compared with weighed food records in young to middle-aged women in a study of iron supplementation. Aust Nz J Publ Heal. 2000;24(6):57683.

13. Ogawa K, Tsubono Y, Nishino Y, Watanabe Y, Ohkubo $\mathrm{T}$, Watanabe $\mathrm{T}$, et al. Validation of a food-frequency questionnaire for cohort studies in rural Japan. Public Health Nutr. 2003;6(2):147-57.

14. Chen Y, Ahsan H, Parvez F, Howe GR. Validity of a foodfrequency questionnaire for a large prospective cohort study in Bangladesh. Br J Nutr. 2004;92(5):851-9.

15. Paalanen L, Mannisto S, Virtanen MJ, Knekt P, Rasanen L, Montonen J, et al. Validity of a food frequency questionnaire varied by age and body mass index. J Clin Epidemiol. 2006;59(9):994-1001.

16. Tokudome S, Imaeda N, Tokudome Y, Fujiwara N, Nagaya T, Sato J, et al. Relative validity of a semi-quantitative food frequency questionnaire versus 28 day weighed diet records in Japanese female dietitians. Eur J Clin Nutr. 2001;55(9):735-42.

17. Sudha V, Radhika G, Sathya RM, Ganesan A, Mohan V. Reproducibility and validity of an intervieweradministered semi-quantitative food frequency questionnaire to assess dietary intake of urban adults in southern India. Int J Food Sci Nutr. 2006;57(7-8):481-93.

18. Marriott LD, Robinson SM, Poole J, Borland SE, Godfrey $\mathrm{KM}$, Law CM, et al. What do babies eat? Evaluation of a food frequency questionnaire to assess the diets of infants aged 6 months. Public Health Nutr. 2008;11(7):751-6.

19. Marriott LD, Inskip HM, Borland SE, Godfrey KM, Law CM, Robinson SM. What do babies eat? Evaluation of a food frequency questionnaire to assess the diets of infants aged 12 months. Public Health Nutr. 2009;12(7):967-72.

20. Holmes B, Dick K, Nelson M. A comparison of four dietary assessment methods in materially deprived households in England. Public Health Nutr. 2008;11(5):444-56.

21. Slater B, Philippi ST, Fisberg RM, Latorre MR. Validation of a semi-quantitative adolescent food frequency questionnaire applied at a public school in Sao Paulo, Brazil. Eur J Clin Nutr. 2003;57(5):629-35.

22. Quandt SA, Vitolins MZ, Smith SL, Tooze JA, Bell RA, Davis $\mathrm{CC}$, et al. Comparative validation of standard, picturesort and meal-based food-frequency questionnaires adapted for an elderly population of low socio-economic status. Public Health Nutr. 2007;10(5):524-32.23.

23. Messerer M, Johansson SE, Wolk A. The validity of questionnaire-based micronutrient intake estimates is increased by including dietary supplement use in Swedish men. J Nutr. 2004;134(7):1800-5.

24. Dumartheray EW, Krieg MA, Cornuz J, Whittamore DR, Lovell DP, Burckhardt P, et al. Validation and reproducibility of a semi-quantitative Food Frequency Questionnaire for use in elderly Swiss women. J Hum Nutr Diet. 2006;19(5):321-30.

25. Mikkelsen TB, Osler M, Olsen SF. Validity of protein, retinol, folic acid and n-3 fatty acid intakes estimated from the food-frequency questionnaire used in the Danish National Birth Cohort. Public Health Nutr. 2006;9(6):771-8.

26. Mouratidou T, Ford F, Fraser RB. Validation of a foodfrequency questionnaire for use in pregnancy. Public Health Nutr. 2006;9(4):515-22.

27. Baer HJ, Blum RE, Rockett HR, Leppert J, Gardner JD, Suitor CW, et al. Use of a food frequency questionnaire in American Indian and Caucasian pregnant women: a validation study. BMC Public Health. 2005;5:135.

28. Ortiz-Andrellucchi A, Sanchez-Villegas A, Doreste- 
Alonso J, de Vries J, de Groot L, Serra-Majem L. Dietary assessment methods for micronutrient intake in elderly people: a systematic review. Br J Nutr. 2009;102 Suppl 1:S118-49.

29. Ortiz-Andrellucchi A, Henriquez-Sanchez P, SanchezVillegas A, Pena-Quintana L, Mendez M, Serra-Majem L. Dietary assessment methods for micronutrient intake in infants, children and adolescents: a systematic review. Br J Nutr. 2009;102 Suppl 1:S87-117.

30. Boucher B, Cotterchio M, Kreiger N, Nadalin V, Block T, Block G. Validity and reliability of the Block98 foodfrequency questionnaire in a sample of Canadian women. Public Health Nutr. 2006;9(1):84-93.

31. Weir RR, Carson EL, Mulhern MS, Laird E, Healy M, Pourshahidi LK. Validation of a food frequency questionnaire to determine vitamin D intakes using the method of triads. J Hum Nutr Diet. 2016;29(2):255-61.

32. Barebring L, Amberntsson A, Winkvist A, Augustin H.
Validation of dietary vitamin D intake from two food frequency questionnaires, using food records and the biomarker 25-Hydroxyvitamin D among pregnant women. Nutrients. 2018;10(6).

33. Magkos F, Manios Y, Babaroutsi E, Sidossis LS. Differences in the quantitative and qualitative performance of a calcium-specific food frequency questionnaire across age and sex. J Hum Nutr Diet. 2006;19(5):331-42.

34. Roman-Vinas B, Ortiz-Andrellucchi A, Mendez M, Sanchez-Villegas A, Pena Quintana L, Aznar LA, et al. Is the food frequency questionnaire suitable to assess micronutrient intake adequacy for infants, children and adolescents? Matern Child Nutr. 2010;6 Suppl 2:112-21.

35. Serra-Majem L, Pfrimer K, Doreste-Alonso J, RibasBarba L, Sanchez-Villegas A, Ortiz-Andrellucchi A, et al. Dietary assessment methods for intakes of iron, calcium, selenium, zinc and iodine. Br J Nutr. 2009;102 Suppl 1:S38-55. 